\title{
Influence of periods of coexistence of weeds on organic okra production
}

\section{Raimundo Nonato Viana Santos ${ }^{1}$, Luciana Lins Oliveira Santos ${ }^{1}$, Luiz Junior Pereira Marques ${ }^{2}$, Antônia Alice Costa Rodrigues ${ }^{1}$, Maria José Pinheiro Correa ${ }^{3}$, Mário Luiz Ribeiro Mesquita ${ }^{4}$, Maria Rosângela Malheiros Silva ${ }^{1}$}

\author{
${ }^{1}$ Universidade Estadual do Maranhão, Centro de Ciências Agrárias, Programa de Pós-Graduação em Agroecologia, São \\ Luís, MA, Brasil \\ ${ }^{2}$ Instituto Federal de Educação, Ciência e Tecnologia do Maranhão, Campus Maracanã, São Luís, MA, Brasil \\ ${ }^{3}$ Departamento de Química e Biologia, Universidade Estadual do Maranhão, São Luís, MA, Brasil \\ ${ }^{4}$ Universidade Estadual do Maranhão, Programa de Pós-Graduação em Agricultura e Ambiente, São Luís, MA, Brasil
}

*Corresponding author: mario-mesquita51@hotmail.com

\begin{abstract}
Weed management in okra grown in organic system minimizes crop yield losses. Thus, the objective of this study was to determine the period prior to weed interference in okra grown in organic system during the rainy and dry seasons in the state of Maranhão, northeastern Brazil. Experiments were conducted in the rainy and dry seasons in randomized block design with seven treatments and four replications. The treatments were T1 = weeds coexistence with okra for 7 days; T2 = coexistence for 14 days; T3= coexistence for 21 days; T4 = coexistence for 28 days; T5 = coexistence for 35 days; T6 = coexistence for 42 days and, T7 = coexistence for 74 days). In addition to these treatments, we kept a control treatment with weed free until harvest to obtain maximum yield. At the end of each period of weed coexistence with the crop, three weed samples were collected in $0.25 \mathrm{~m}^{2}$ to evaluate density, dry mass and to analise phytosociological parameters. The main weeds in both seasons were Commelina benghalensis, Cynodon dactylon, Eleusine indica, Alternanthera tenella and Amaranthus spinosus. The coexistence of weeds with the crop until harvest caused losses of $51 \%$ in the rainy season and $67 \%$ in the dry season compared to weed free control. In the rainy season, the period before weed interference (PBI) on okra crop of organic system was 12 days after emergence (DAE). In the dry season, $5 \%$ yield loss was observed 4 days after transplanting (DAT). Weed management in organic okra should be carried out earlier in the dry season than in the rainy season to avoid high yield losses.
\end{abstract}

Keywords: Abelmoschus esculentus (L.) Moench; competition; phytosociology; weed community; yield.

Abbreviations: CPIP_critical period of weed control; TPIP_total period of interference prevention; PBI_period before interference DAE_days after emergence; DAT_days after transplanting; IVI_Importance Value Index.

Introduction

In Brazil, the okra crop [Abelmoschus esculentus (L.) Moench] has excellent conditions for growth and development, especially regarding climatic factors in the northeast and southeast regions (Santos et al., 2010). In the northeast, okra is a vegetable grown and is consumed mainly by family farmers, particularly in the rural area of São Luís island, in the state of Maranhão. Okra is traditionally grown in conventional system in the rural area of São Luís island, but there is a growing interest in okra production in organic system due to greater economic return and less negative impact of okra grown conventional system on human health and the environment. Okra production is influenced by several biological factors such as pests and diseases, but weed occurrence is the main problem that cause yield losses. Unchecked weed growth in conventional system, may cause yield losses ranging from
88.54\% to 95\% (Santos et al., 2010; Bachega et al., 2013; lyagba et al., 2013; Omovbude and Udensi, 2018).

Information about yield loss in okra grown due to weeds in organic system is scarce. Weed management is a challenge to obtain high yield due to the inability of okra to prevent weed growth in early stages of crop establishment (Omovbude and Udensi, 2018).

Among the various strategies to minimize adverse effects of weeds on agricultural systems is determination of the critical weed control period, defined by Pitelli and Durigan (1984) as the period when weed control must be performed to prevent interference with productivity and other crop characteristics. The critical period of weed control (CPIP) is formed by two distinct periods, the Total Period of Interference Prevention (TPIP) and the Period Before Interference (PBI). These factors were conceptualized by Pitelli and Durigan (1984) as the 
period, after which weed growth and recruitment of resources by emerging weeds will not harm the crop and the period from the emergence that crop can coexist with the weeds without decreasing yield, respectively.

Several studies addressed the PBI of okra in conventional system (Santos et al., 2010; Awodoyin and Olubode, 2011; Bachega et al., 2013; Adeyemi et al., 2016). However, there is little information about okra grown in organic system, especially in the dry and rainy seasons of tropics.

The influence of the climatic season on crops and weeds has been reported by Olabode et al. (2010) as a consequence of water availability that probably promotes greater competition in the dry season than in the rainy season and affects the critical period of weed interference in crops. In addition, the high abundance of weeds in the organic cropping systems (Smith et al., 2010) may affect crop yield. Therefore, knowledge of $\mathrm{PBI}$ in different climatic seasons in the okra grown in organic system is the first step to avoid unnecessary costs for weed management, especially in a crop such as okra that requires high weeding labor.

In this context, this research hypothesised that in the organic system, the dry season reduces the PBI in okra crop due to greater competition for water and nutrients between crop and weeds. The objective of this study was to determine the PBI in okra grown in organic system in the rainy and dry seasons.

\section{Results and discussion}

\section{Effect of season on the weed community}

We identified 41 weed species during the rainy season and 25 in the dry season (Table 1). The rainy season increased the weed species richness that coexisted with okra, probably due to the greater availability of water for germination of many weeds. Adeyemi et al. (2016), found 26 weed species at the beginning and only 20 species at the end of the rainy season in okra grown in conventional system.

Bachega et al. (2013), lyagba et al. (2013) and Adeyemi et al. (2016) also observed greater weed species richness in okra grown in organic system than in conventional system.

In the rainy season, we found 17 families. The highest species richness were: Poaceae $(n=9)$, Amaranthaceae $(n=6)$ and Cyperaceae $(n=5)$, while in the dry season there were 14 families and those with higher species richness were Poaceae and Amaranthaceae with three species each (Table 1). The rainy season increased the number of families and species of the Poaceae and Amaranthaceae families compared to the dry season, and favored species humid environment friendly such as those of the family Cyperaceae.

In okra crop grown with organic fertilization in the rainy season, Dada and Fayinminnu (2010) emphasized the family Poaceae with six and Cyperaceae with four species, as predominant. However, in conventional system in Nigeria, Adeyemi et al. (2016) observed only the Poaceae family with the largest number of species in the rainy and dry seasons with seven and six species, respectively. Most species from Poaceae produce a high amount of diaspores, which facilitate their dissemination and establishment in several environments (Kissmann and Groth, 1997).

Weed density decreased as coexistence periods in both climatic seasons increased. The highest density was obtained during the rainy season, by which they reached 701 and 643 plants $\mathrm{m}^{-2}$, respectively (Figure 2). The initial high density of weeds in the at 7 and 14 days rainy season was probably due to the higher rainfall, favoring the emergence and regrowth of fragmented aerial parts during mowing. The reduction in weed density at the end of the coexistence period is explained by the shading of the crop canopy and the intraspecific competition. In Nigeria, lyagba et al. (2013) found no differences in weed density ( 33 plants $\mathrm{m}^{-2}$ ) between rainy and dry seasons in conventional okra cultivation. Omovbude and Udensi (2018) observed high weed density in the rainy season (948.11 plants $\mathrm{m}^{-2}$ ) compared to the dry season (533.89 plants $\mathrm{m}-2$ ). The authors attributed this result to differences in rainfall between the seasons.

Weed dry matter accumulation in the two seasons increased with periods of coexistence, mainly in the rainy season. Weeds accumulated $232.07 \mathrm{~g} \mathrm{~m}^{-2}$ at 42 days in the rainy season and $107.37 \mathrm{~g} \mathrm{~m}^{-2}$ in the dry season (Figure 3). The increased rainfall availability contributed to the development of some species probably due to greater recruitment of nutrients in the soil.

Omovbude and Udensi (2018) also found higher weed dry mass accumulation in the rainy season $\left(257.22 \mathrm{~g} \mathrm{~m}^{-2}\right)$ than in the dry season $\left(96.11 \mathrm{~g} \mathrm{~m}^{-2}\right.$ ) in conventional okra cultivation. The species with the highest importance value indexes (IVI) in rainy season were $A$. tenella, $C$. benghalensis, $C$. dactylon and $P$. niruri, and in the dry season, $C$. dactylon, E. indica, $A$. spinosus and $C$. benghalensis (Figure $4 a$ and $b$ ).

The climatic season changed the population dynamics of the weed community during the crop growth and development, evidencing the importance of the phytosociological studies in these seasons to adjust weed management.

In the rainy season, $C$. benghalensis had the highest IVI, with values ranging from $74.85 \%$ to $93.48 \%$, except for 14 and 21 DAE when $A$. tenella increased its participation in the weed community with IVI of $85.27 \%$ and $58.81 \%$, respectively (Figure 4a).

Moisture during the rainy season probably increased $C$. benghalensis and $A$. tenella infestation due to regrowth of fragmented parts during mowing and the seed germination and emergence from cattle manure applied for okra fetilization.

Riar et al. (2014) observed that in rumen digestion simulation, C. benghalensis seeds were not much affected in their germination. Thus, it is assumed that the manure used also contributed to the spread of $C$. benghalensis. Dada and Fayinminnu, (2010) and Omovbude and Udensi (2018) also showed the presence of $C$. benghalensis in okra cultivation in the organic and conventional systems, respectively. Santos et al. (2010) cited $A$. tenella among the main weed species in conventional okra cultivation.

Another important species observed at the beginning of the rainy season was C. dactylon with IVI of $66.44 \%$, but its importance decreased during the crop cycle by $C$. benghalensis and $A$. tenella (Figure 4a). C. dactylon was also favored by the mechanical control used in soil preparation that fragmented and dispersed its stolons and rhizomes. However, higher soil moisture during the rainy season promoted higher growth of C. benghalensis and $A$. tenella.

In the dry season, $C$. dactylon had the highest IVI with values ranging between $42.48 \%$ and $48.54 \%$, followed by $E$. indica 
Table 1. List of families, species of the weeds identified in the periods of coexistence with okra during the rainy $2013 / 2014$ and dry season 2014/2015 in São Luís, state of Maranhão, northeastern Brazil.

\begin{tabular}{|c|c|c|c|}
\hline Fami & Species & $\begin{array}{l}\text { Rainy } \\
\text { season }\end{array}$ & $\begin{array}{l}\text { Dry } \\
\text { season }\end{array}$ \\
\hline \multirow{7}{*}{ AMARANTHACEAE } & Alternanthera tenella Colla & $\mathrm{P}^{*}$ & $P$ \\
\hline & Amaranthus deflexus L. & $P$ & $P$ \\
\hline & Amaranthus retroflexus L. & $\mathrm{P}$ & -- \\
\hline & Amaranthus spinosus L. & $\mathrm{P}$ & $P$ \\
\hline & Amaranthus viridis $\mathrm{L}$. & $\mathrm{P}$ & -- \\
\hline & Amaranthus sp & $\mathrm{P}$ & $P$ \\
\hline & Ageratum conyzoides L. & -- & $\mathrm{P}$ \\
\hline \multirow[t]{3}{*}{ ASTERACEAE } & Eclipta alba (L.) Hassk. & $\mathrm{P}$ & $\mathrm{P}$ \\
\hline & Emilia sonchifolia (L.) DC & $\mathrm{P}$ & -- \\
\hline & Synedrella nodiflora (L.) Gaertn. & $\mathrm{P}$ & -- \\
\hline BORAGINACEAE & Heliotropium indicum $\mathrm{L}$. & $\mathrm{P}$ & -- \\
\hline \multirow[t]{5}{*}{ CLEOMACEAE } & Hemiscola aculeata (L.) Raf. & $P$ & $P$ \\
\hline & Cyperus sp & $\mathrm{P}$ & $\mathrm{P}$ \\
\hline & Cyperus flavus (Vahl) Nees & & -- \\
\hline & Cyperus distans L.f. & $P$ & $\mathrm{P}$ \\
\hline & Cyperus brevifolius (Rottb.) Hassk. & $\mathrm{P}$ & -- \\
\hline \multirow[t]{3}{*}{ CYPERACEAE } & Cyperus sphacelatus & -- & $P$ \\
\hline & Bulbostylis capillaris (L.) C.B. Clarke. & $\mathrm{P}$ & -- \\
\hline & Kyllinga odorata Vahl & $\mathrm{P}$ & -- \\
\hline COMMELINACEAE & Commelina benghalensis $\mathrm{L}$. & $\mathrm{P}$ & $\mathrm{P}$ \\
\hline \multirow[t]{2}{*}{ EUPHORBIACEAE } & Chamaesyce hirta (L.) Millsp & $\mathrm{P}$ & $P$ \\
\hline & Euphorbia heterophylla L. & $\mathrm{P}$ & -- \\
\hline LINDERNIACEAE & Lindernia crustacea (L.) F. Muell. & $\mathrm{P}$ & $\mathrm{P}$ \\
\hline \multirow[t]{2}{*}{ LOGANIACEAE } & Spigelia anthelmia $\mathrm{L}$. & $\mathrm{P}$ & -- \\
\hline & Sida $\mathrm{sp}$ & $\mathrm{P}$ & -- \\
\hline \multirow[t]{2}{*}{ MALVACEAE } & Gaya pilosa K. Schum. & $\mathrm{P}$ & -- \\
\hline & Corchorus argutus Kunth & $\mathrm{P}$ & $\mathrm{P}$ \\
\hline MOLLUGINACEAE & Mollugo verticillata $\mathrm{L}$. & $\mathrm{P}$ & $\mathrm{P}$ \\
\hline NYCTAGINACEAE & Boerhavia diffusa $\mathrm{L}$. & $\mathrm{P}$ & -- \\
\hline ONAGRACEAE & Ludwigia octovalvis (Jacq.) PH. Raven & $\mathrm{P}$ & $\mathrm{P}$ \\
\hline \multirow{10}{*}{ POACEAE } & Cynodon dactylon (L.) Pers. & $P$ & $\mathrm{P}$ \\
\hline & Eleusine indica (L.) Gaertn. & $\mathrm{P}$ & $\mathrm{P}$ \\
\hline & Digitaria sp & $\mathrm{P}$ & $\mathrm{P}$ \\
\hline & Cenchrus echinatus L. & $\mathrm{P}$ & -- \\
\hline & Paspalum maritimum Trin. & $\mathrm{P}$ & $P$ \\
\hline & Panicum maximum Jacq. & $\mathrm{P}$ & -- \\
\hline & Panicum sp & $\mathrm{P}$ & -- \\
\hline & Brachiaria sp & $\mathrm{P}$ & -- \\
\hline & Brachiaria mutica (Forssk.) Stapf & $\mathrm{P}$ & -- \\
\hline & Eragrostis ciliares (L.) R. Br. & & -- \\
\hline \multirow{2}{*}{ PORTULACACEAE } & Portulaca oleracea L. & $\mathrm{P}$ & $P$ \\
\hline & Talinum triangulare (Jacq.) Willd. & $\mathrm{P}$ & -- \\
\hline PHYLLANTHACEAE & Phyllanthus niruri L. & $\mathrm{P}$ & $P$ \\
\hline \multirow{2}{*}{ RUBIACEAE } & Hedyotis corymbosa (L.) F. Muell & $\mathrm{P}$ & $\mathrm{P}$ \\
\hline & Spermacoce latifolia Aubl. & $\mathrm{P}$ & $\mathrm{P}$ \\
\hline
\end{tabular}

*Presence (P) and Absent (--) 

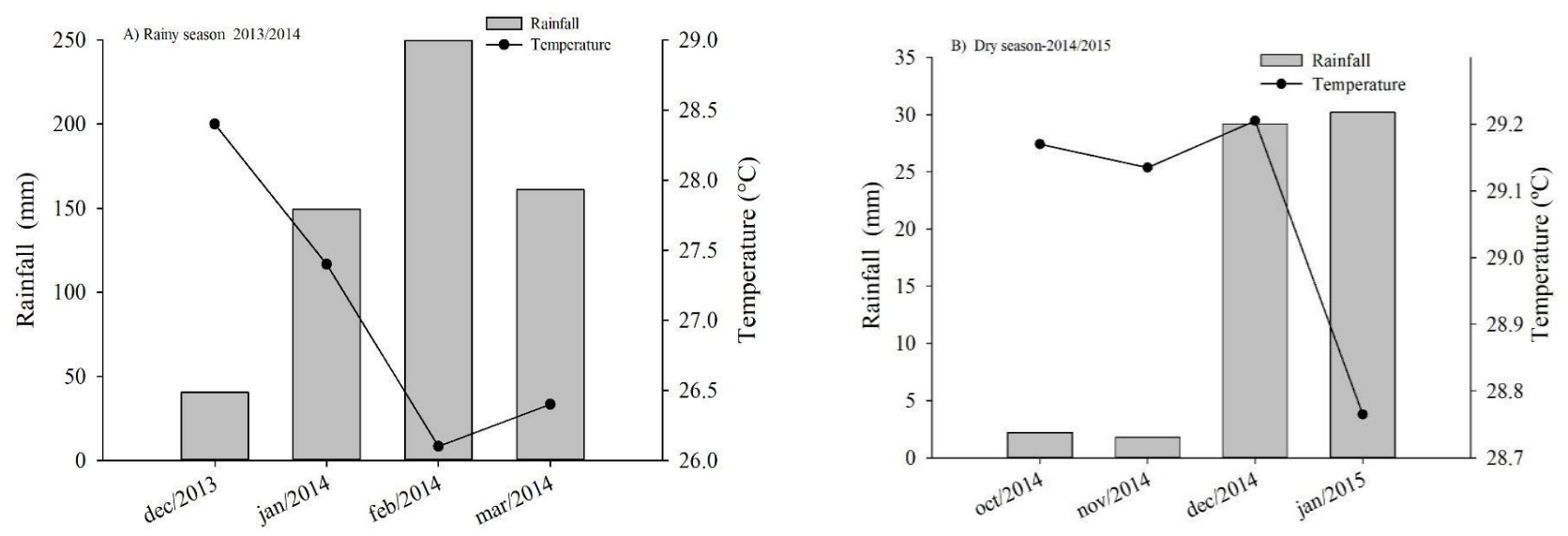

Fig 1. Rainfall and mean temperature in the rainy season 2013/2014 (A) and in the dry season 2014/2015 (B) during the experiment of coexistence of weeds with okra grown in organic cropping system in São Luís, state of Maranhão, northeastern Brazil. Source: Núcleo Geoambiental (Nugeo), 2015.

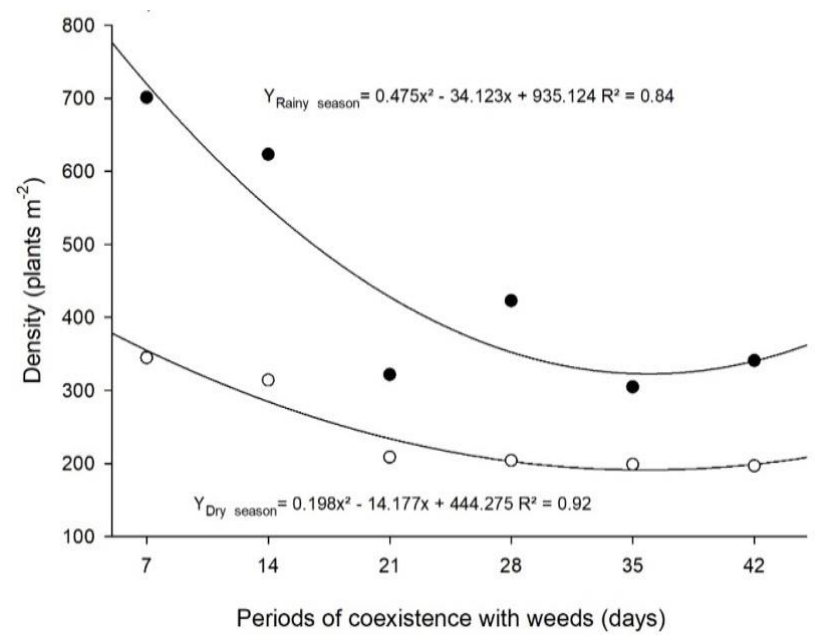

Fig 2. Weed density upon treatmens of coexistence periods with okra grown in organic system during the rainy season $2013 / 2014$ and the dry season 2014/2015 in São Luís, state of Maranhão, northeastern Brazil.

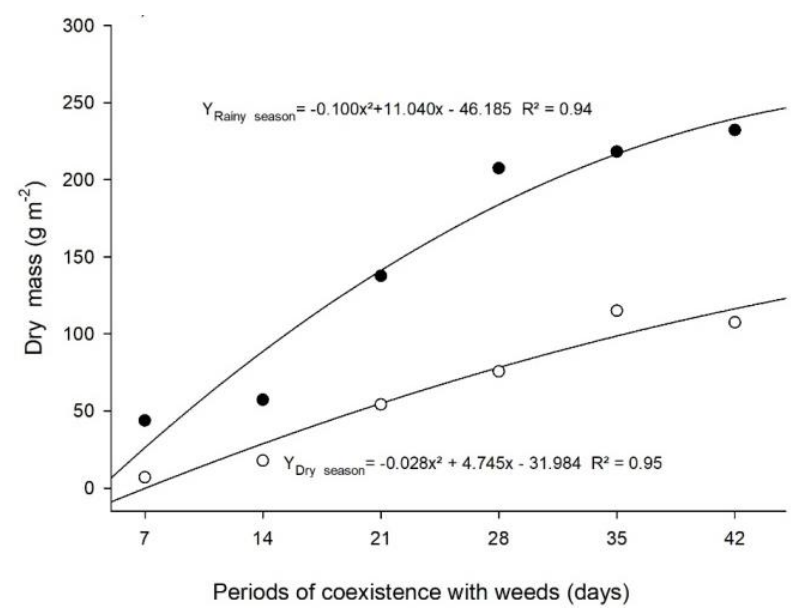

Fig 3. Weed dry mass in the treatments of coexistence periods with okra grown in organic system during the rainy season $2013 / 2014$ and the dry season 2014/2015 in São Luís, state of Maranhão, northeastern Brazil. 

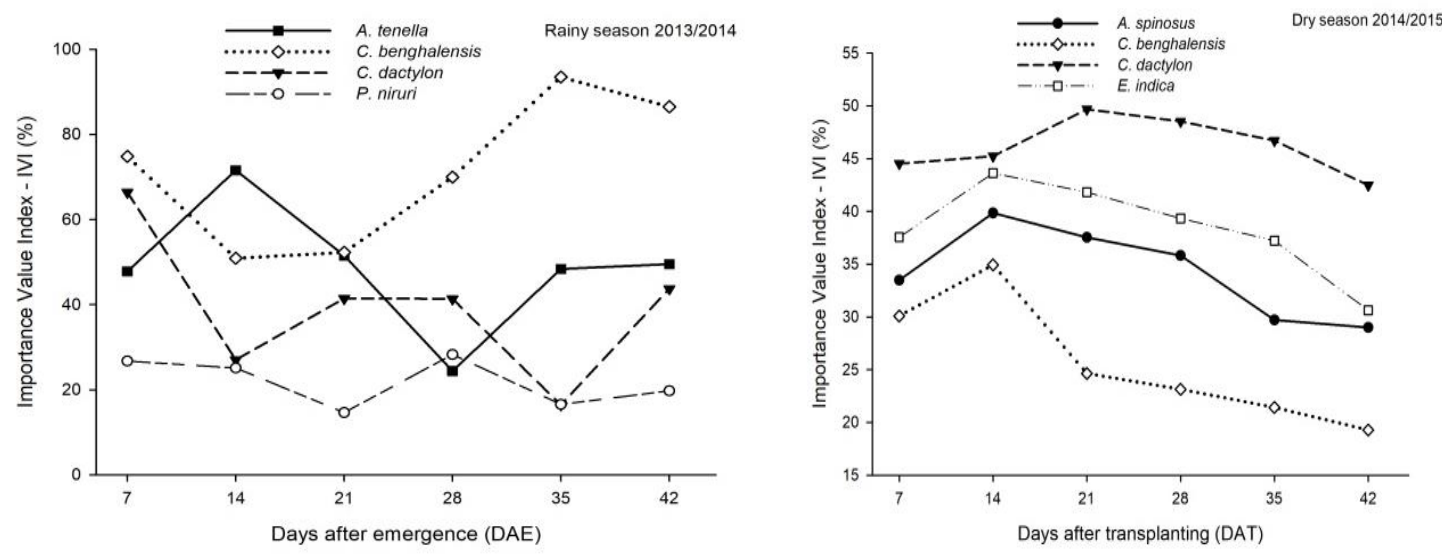

Fig 4. Importance Value Index (IVI) of the main weeds upon tratments of coexistence with okra grown in organic system during the rainy season 2013/2014 (A) and the dry season 2014/2015(B) in São Luís, state of Maranhão, northeastern Brazil.

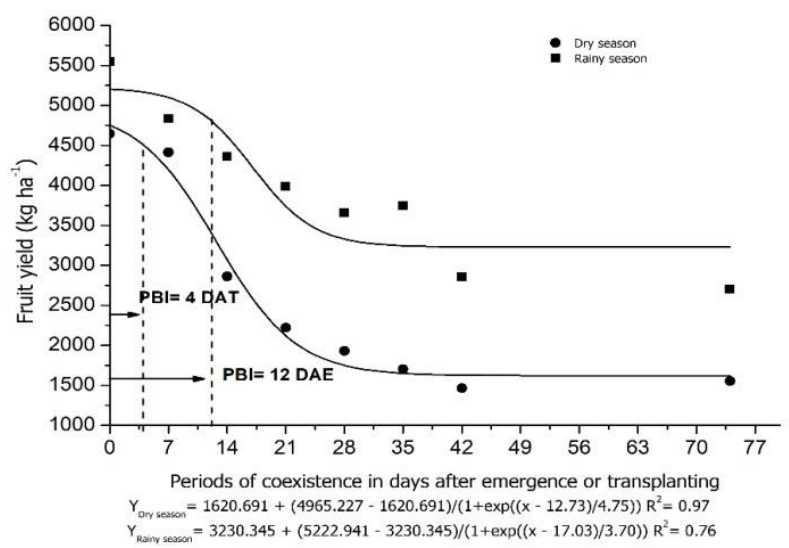

Fig 5. Comercial okra fruit yield during the rainy season 2013/2014 and the dry season 2014/2015 grown in organic system and adjustment by the Boltzmann sigmoid model, due to treatments of coexistence with weeds, considering okra yield loss of $5 \%$, in São Luís, state of Maranhão, northeastern Brazil.

with IVI values from $30.63 \%$ to $43.64 \%$ and $A$. spinosus with values ranging from $28.99 \%$ to $39.86 \%$ (Figure $4 b$ ). The greater participation of $C$. dactylon and $E$. indica is related to their capacity of drought tolerance and photosynthesis by the $\mathrm{C} 4$ pathway, with water use efficiency (Kissmann and Groth, 1997). These characteristics provided greater competitive ability, particularly for $C$. dactylon, which increased its infestation by fragmentation of stolons and rhizomes during mowing and opening of furrows in the soil.

Dada and Fayinminnu, (2010) and Adeyemi et al. (2016) also observed $C$. dactylon and $E$. indica in the weed community of okra in organic and conventional systems, respectively. This indicates the great plasticity of these two species with adaptability to different okra cropping systems.

The presence of $A$. spinosus from seven to 28 DAT with IVI of $35.82 \%$ made control of cultural practices difficult to control the weeds during okra fruit harvest due to the presence of spines and shrub behavior (Figure $4 \mathrm{~b}$ ). Its relevance in the dry season was probably due to the high temperatures and tolerance to water stress that stimulated its emergence. Chauhan and Abugho (2013) reported this species as an important weed in rice crop that withstands high water stress due to its C4 photosynthetic pathway that minimizes water loss in hot and dry environments.

C. benghalensis showed low IVI during the crop cycle in dry season, compared with the rainy season. The highest values were occurred at seven DAT (30.09\%) and at 14 DAT (34.94\%), decreasing from 21 DAT to 42 DAT (Figure 4b). It is inferred that the lower availability of water in the dry season probably interfered with the growth of $C$. benghalensis, where had a high IVI at 35 DAE of $93.4 \%$ in the rainy season. Webster and Gray (2008) reported that $C$. benghalensis does not support water stress due to its fibrous root system that is close to the soil surface.

The climatic seasons affected the PBI of weeds in okra grown in organic system. In the rainy season, the extent of weed coexistence was up to $12 \mathrm{DAE}$, while in the dry season it was reduced to 4 DAT, considering a maximum yield loss of $5 \%$ (Figure 5). The higher soil moisture available during the rainy season under organic system promoted more weed tolerance compared to the dry season. This is the crop coexisted with weeds at the beginning of its growth during the rainy season 
without affecting production. However, Dada and Fayinminnu (2010) observed greater weed coexistence (21 days) with the crop in okra grown in organic system in the rainy season, probably due to less aggressiveness of the weed community. Comparison of the results observed in this study with those carried out in conventional system by Santos et al. (2010) and Bachega et al. (2013) revealed longer periods of weed coexistence, 25 and $57 \mathrm{DAE}$, respectively. It is inferred that differences in coexistence periods between okra cultivation systems are related to weed management practices that select different species, to crop species and to edaphoclimatic conditions. Therefore, the determination of the period of coexistence of weeds with okra in an organic system is important to implement the management practices of these species and avoid yield losses.

\section{Effect of season on okra crop yield}

The okra weed free yield in the rainy season was $5,546.87 \mathrm{~kg}$ $\mathrm{ha}^{-1}$ in coexistence with weeds, $2,703.12 \mathrm{~kg} \mathrm{ha}^{-1}$ resulting in $51 \%$ yield losses. On the other hand, okra weed free yield in the dry season was $4,645.31 \mathrm{~kg} \mathrm{ha}^{-1}$ and, in coexistence with weeds, $1,550.87 \mathrm{~kg} \mathrm{ha}^{-1}$ with yield losses of $67 \%$. This indicates that in okra grown in organic system yield losses are lower in the rainy season than in the dry season, although weed density and dry mass accumulation were high during the rainy season. Smith et al. (2010) reported that diversified cropping systems provide nutrients in various forms to weeds and crops. Thus, probably the amount of water and the diverse forms of nutrients are available by the organic system during the season met weed and crop needs resulting in less competition and yield losses.

Awodoyin and Olubode (2011) and Adeyemi et al. (2016) in okra grown in conventional system in Nigeria found higher yield losses of 92.2 and $84.97 \%$, in the dry season than in the rainy season due to weed interference, respectively. Therefore, regardless of okra cultivation system, weed interference during the dry season increases competition and crop yield losses.

\section{Materials and Methods}

\section{Study site}

The experiments were conducted in the rainy season, from December 2013 to March 2014 and in the dry season, from October 2014 to January 2015, in a certified organic production area in the municipality of São Luís, state of Maranhão, northeastern Brazil $\left(2^{\circ} 37^{\prime} \mathrm{S}\right.$ and longitude $44^{\circ} 11$ '15 "W). The local climate is of type Aw according to the Köppen classification, hot and humid, equatorial, with a rainy season from January to June (average of $2,010 \mathrm{~mm}$ ) and a dry season from July to December with a mean annual temperature of $26.1^{\circ} \mathrm{C}$, with variations of $30.4^{\circ} \mathrm{C}$ and $23.3^{\circ} \mathrm{C}$, and the mean relative humidity of $88 \%$ (Instituto Nacional de Meteorologia, 2009).

The climatological data regarding temperature and mean precipitation during the conduction of the experiments are in Figure 1. The soil is classified as Red-Yellow Distrophic Arenic Argisol (Santos et al., 2013), sandy loam texture with 20 dag kg ${ }^{-1}$ of coarse sand, $64 \mathrm{dag} \mathrm{kg}^{-1}$ of fine sand, $8 \mathrm{dag} \mathrm{kg}^{-1}$ of silt and
8 dag $\mathrm{kg}^{-1}$ of clay. The chemical characteristics were Organic Matter $=26 \mathrm{~g} \mathrm{dm}^{-3} ; \mathrm{pH} \mathrm{CaCl}_{2}=5.4 ; \mathrm{P}=111 \mathrm{mg} \mathrm{dm}^{-3} ; \mathrm{K}=2.3, \mathrm{Ca}$ $=33, \mathrm{Mg}=14, \mathrm{SB}=49.3, \mathrm{H}+\mathrm{Al}=26$, and $\mathrm{CEC}=75.3 \mathrm{mmolc} \mathrm{dm}$ ${ }^{3} ; \mathrm{V}=65 \%, \mathrm{~K} / \mathrm{CTC}=3.1 \%$ and $\mathrm{Mg} / \mathrm{CTC}=18.6 \%$.

Soil preparation was done by means of mowing and opening of furrows with a microtractor. Planting fertilization consisted of $27.80 \mathrm{t} \mathrm{ha}^{-1}$ of chicken manure, $0.46 \mathrm{t} \mathrm{ha}^{-1}$ of natural phosphate, $0.023 \mathrm{t} \mathrm{ha}^{-1}$ of potassium sulfate and $0.20 \mathrm{t} \mathrm{ha}^{-1}$ of ash. Foliar fertilization was carried out at 31 days after transplanting (DAT) with a biofertilizer from bovine and cane bagasse for $180 \mathrm{~L}^{-1}$ in the proportion of $0.5 \mathrm{~L}$ to $20 \mathrm{~L}$ of water.

\section{Plant materials}

The cultivar used in the experiments was the early mature Valença, with flowering at approximately 40 DAT. For the experiment carried out in the rainy season, the okra seeds were immersed in water for 24 hours to break dormancy and then sown in the field, whereas for the experiment carried in the dry season, the seeds were sown in trays to obtain seedlings. These were transplanted when they had two definitive leaves.

\section{Experimental design}

The experiments were conducted in the rainy and dry season in randomized complete block design with seven treatments and four replications in a factorial scheme $(2 \times 7)$ represented by two climatic seasons (rainy and dry) and seven periods of coexistence of the weeds with okra crop. The treatments were okra coexistence with weeds for 7 days (T1), 14 days (T2), 21 days (T3), 28 days (T4), 35 days (T5), 42 days (T7) and 74 days (T8). In addition, we kept a control treatment with okra weed free until harvest to obtain maximum yield. At the end of each coexistence period, weeds were identified, counted and removed by weeding until the beginning of the harvest to verify the crop yield. The experimental plots consisted of four rows of $3.20 \mathrm{~m}$ long spaced $1.00 \mathrm{~m}$ between rows and $0.40 \mathrm{~m}$ between plants within rows, making up $12.8 \mathrm{~m}^{2}$. The useful area of the harvest plot was the two central rows, excluding $0.40 \mathrm{~m}$ from the ends, totaling $4.8 \mathrm{~m}^{2}$. During the dry season, the plots were sprinkling irrigated by a $495 \mathrm{~mm}$ irrigation depth.

\section{Assessment of weed density, dry weight and phytosociological parameters}

Weed evaluations were carried out by means of three random samples, in the useful area of the plots, using $0.50 \mathrm{~m} \times 0.50 \mathrm{~m}$ metal quadrat. The aerial parts of the plants inside the quadrat perimeter were harvested, counted, identified and oven dried with forced air ventilation at $65-70{ }^{\circ} \mathrm{C}$ for 72 hours. The samples were weighed in a $0.01 \mathrm{~g}$ precision scale.

The weed density and dry mass were expressed as number of plants $\mathrm{m}^{-2}$ and grams of dry mass $\mathrm{m}^{-2}$. These data from each weed population were used to determine the phytosociological parameters: relative density, absolute and relative frequency, relative dominance, and importance value index. Each of these parameters was determined after application of specific formulas, according to Mueller-Dombois 
and Ellemberg (1974).

\section{Assessment of okra fruit yield}

In both climatic seasons, the harvests started at 45 days when the fruits showed commercial standard. The fruits were harvested in the useful area of the plots, by manual cutting close to the peduncle, every two days and weighed on a $0.01 \mathrm{~g}$ precision scale. Fruit yield was expressed in $\mathrm{kg} \mathrm{ha}^{-1}$. The harvests ended at 74 days, when they totaled 13 harvests that represented the total crop yield.

\section{Statistical analysis}

The results of weeds density and crop production by treatment were submitted to analysis of variance by the $F$ test at $5 \%$ probability and the means were compared by the Tukey test at 5\% (Barbosa and Maldonado, 2010). The period before interference (PBI) of weeds in the okra crop was estimated based on regression equations of Boltzamnn, accepting the arbitrary of $5 \%$ level of production reduction.

The Boltzman's sigmoidal model (Originlab Corporation, 2002) follows the equation $Y=A 2+((A 1-A 2) /(1+\exp (X-$ $X 0) / d X))$, where $Y=$ okra yield $\left(\mathrm{kg} \mathrm{ha}^{-1}\right) ; \mathrm{X}=$ upper limit of the coexistence period; $X_{0}=$ upper limit of the coexistence period corresponding to the turning point of the curve $\mathrm{A} 1=$ maximum yield in the control treatment with weed control and $\mathrm{A} 2$ = minimum yield in coexistence treatment until harvest; $d X$ $=$ indicates the rate of production loss (tg $\alpha$ at point $\mathrm{X} 0$ ).

\section{Conclusions}

Organic okra grown in organic system had higher weed tolerance at the beginning of its growth in the rainy season than in the dry season. The coexistence of okra with weeds during the dry season resulted in higher yield losses due to intensified competition for environmental resources. Thus, weed management in okra grown in organic system should be carried out early in the dry season to avoid high yield losses.

\section{Acknowledgments}

Thanks to the Foundation for Research Support in the State of Maranhão (FAPEMA) for the funding of the research and the Coordination for the Improvement of Higher Education Personnel (CAPES) for granting the scholarship to the first author and to Empresa Alimentum Ltda for making the field area available.

\section{References}

Adeyemi OR, Smith, MAK, Ojeniyi, SO, Olubode, OO (2016) Effects of time of weed removal on weed species composition and crop performance of okra (Abelmoschus esculentus L.). J Biol Agric and Health. 6: 34-42.

Awodoyin RO, Olubode OS (2011) Assessment of critical period of weed interference in okra (Abelmoschus esculentus L.) field in Ibadan, a rainforest-savanna transition eco-zone of
Nigeria. Acta Hortic. 911: $99-111$.

Bachega LPS, Carvalho LB, Bianco S, Filho ABC (2013) Períodos de interferência de plantas daninhas na cultura do quiabo. Planta Daninha. 31: 63 - 70.

Barbosa JC, Maldonado Júnior W AgroEstat: sistema para análises estatísticas de ensaios agronômicos. versão 1.1. Jaboticabal: Departamento de Ciências Exatas. 2010.

Chauhan BS, Abugho SB (2013) Effect of water stress on the growth and development of Amaranthus spinosus, Leptochloa chinensis and rice. Am J Plant Sci. 4: 989 - 998.

Dada OA, Fayinminnu OO (2010) Period of weed control in okra (Abelmoschus esculentus L.) as influenced by varying rates of cattle dung and weeding regimes. Not Bot Horti Agrobo. 38: 149 - 154.

Fennimore SA, Smith RF, Tourte L, LeStrange M, Rachuy JS (2014) Evaluation and economics of a rotating cultivator in bok choy, celery, lettuce, and radicchio. Weed Technol. 28:176-188.

Instituto Nacional de Meteorologia. Normas climatológicas do Brasil 1961-1990. Brasília, DF. 2009. 465p.

lyagba AG, Onuegbu BA, Ibe AE (2013) Growth and yield response of okra (Abelmoschus esculentus L.) to NPK fertilizer rates and weed interference in South-eastern Nigeria. Glob J Agric Sci. 1:087-094.

Kissmann KG, Groth D (1997) Plantas infestantes e nocivas. Tomo 1. 2ed. São Paulo: BASF. 826p.

Mueller-Dombois E, Ellenberg H (1974) Aims and methods of vegetation ecology. New York: John Wiley e Sons, 547p.

Núcleo Geoambiental. Laboratório de MeteorologiaInformativo Climático. 2015.

Originlab Corporation (2002) Origin 8.0 origin user guide. 246p.

Omovbude S, Udensi EU (2018) Response of okra (Abelmoschus esculentus (L.) Moench) and weeds to plant spacing and weeding regime in a humid forest agro-ecology of south-eastern Nigeria. J Appl Life Sci Int. 18: 1-13.

Pitelli RA, Durigan JC (1984) Terminologia para períodos de controle e de convivência das plantas daninhas em culturas anuais e bianuais. In: Congresso Brasileiro de Herbicidas e Plantas Daninhas, 15, 1984, Belo Horizonte. Resumos. Piracicaba: SBHED, p.37.

Pitelli RA (2000) Estudos fitossociológicos em comunidades infestantes de agroecossistemas. J ConsHerb. 1: 1- 7.

Riar MK, Spears JF, Burns JC, Jordan DL, Zhang C, Rufty TW (2014) Persistence of benghal dayflower (Commelina benghalensis) in sustainable agronomic systems: potential impacts of hay bale storage, animal digestion, and cultivation. Agroecol Sust Food. 38: 283 - 298.

Santos JB, Silveira TP, Coelho PS, Costa OG, Matta PM, Silva $M B$, Drumond Neto AP (2010) Interferência de plantas daninhas na cultura do quiabo. Planta Daninha. 28: 255 262.

Santos HG, Jacomine PKT, Anjos LHC, Oliveira VAV, Lumbreras JF, Coelho MR, Almeida J A, Cunha TJF \& Oliveira JB (2013) Sistema brasileiro de classificação de solos. 3a ed. Brasília, Embrapa. 353p.

Webster TM, Grey TL (2008) Growth and reproduction of benghal dayflower (Commelina benghalensis) in response to drought stress. Weed Sci. 56: 561 - 566. 